\title{
Advanced and Commonly Used Serological Techniques for Detection and Diagnosis of Plant Virus: Review
}

\author{
Bayissa Regassa* Daniel Ketsela Mezgebu Debalo \\ Ethiopia Institute of Agricultural Research, Ambo Agricultural Research Center, P. O. Box 37, Ambo, Ethiopia
}

\begin{abstract}
Plant diseases caused by viruses are the most menace to sustainable agriculture, leading to numerous billion dollars in losses annually. Proper and accurate detection of plant viruses is always the key to developing appropriate solutions to manage the economic losses caused by them. Advances in technology have simplified the tools available to detect and diagnose viruses at a time when control measures should be used. Currently, nucleic acid and serological based diagnostic methods are widely used for plant viral identifications. Serological techniques which based on antibody and antigen reaction is broadly used for the detection of plant viruses because of its simplicity, adaptability and sensitivity. A large number of advanced serological tests are available such as enzymelinked immunosorbent assay (ELISA), dot immunobinding assay, tissue blotting immunoassay and Lateral flow assay. Various ELISA varieties such as double-antibody sandwich- ELISA, triple-antibody sandwich-ELISA, and antigen-coated-ELISA are widely used in the detection and testing of plant viruses. Dot immunobinding assay performed on a nitrocellulose that the plant extracts are spotted onto a membrane while tissue blotting immunoassay is an easy method that the crude sap from plants is directly blotted and used for detection through immunology. Lateral flow assay is the latest and the only serological method used for the detection of viruses without the aid of laboratory and skilled personnel. It is an onsite and quick assay that can be performed by anyone and suitable for the detection of viruses that occur in high concentrations in plants.
\end{abstract}

Keywords: Antibody, Antigen, ELISA, Plant virus, Detection, Serology

DOI: $10.7176 /$ ALST/91-02

Publication date: January $31^{\text {st }} 2022$

\section{Introduction}

Plant diseases are responsible for major economic losses in agricultural production worldwide. The losses in crop yield due to pathogen infections range between $20 \%$ and $40 \%$ (Savary et al., 2012). Among plant pathogens, plant virus infections affect seriously agricultural products around the world. Plant virus disease cause about $40 \%$ of total crop losses and results in the loss of billions of dollars per year by limiting plant product quality and quantity (Maksimov et al., 2019; Han`cinský et al., 2020).

There are no economically feasible chemical agents similar to fungicides and bactericides that are effective for plant virus disease management. The approach intended at plant virus disease management is largely directed at preventing virus infection by eradicating the source of infection to prevent the virus from reaching the crop, reducing the spread of the disease by controlling its vector, use of virus-free planting material, and incorporating host-plant resistance to the virus. Management or to minimize the disease-induced damage in crops during growth, harvest and postharvest processing, as well as to maximize productivity, and ensure agricultural sustainability, advanced disease detection and prevention in crops are highly important. The prevention measures demand pathogen detection methods of high sensitivity, specificity and reliability (Mehetre et al., 2021).

Plant virus infections are emerging as major concerns in improving agricultural productivity. In recent years, large numbers of plant viruses have already appeared and sprouted in various agro-ecological locations. Assessing their ongoing prevalence is a key requirement for early and effective diagnosis (Varma and Singh, 2020; Mehetre et al., 2021). Recent advances in techniques for the detection of proteins and nucleic acids have provided an opportunity to develop methods with these qualities for the detection and diagnosis of plant virus diseases. The kind of diagnostic test used ultimately depends on resources, facilities, availability of reagents, level of specificity and sensitivity required expertise and skills available to carry out these assays, type and number of samples to be tested, and the amount of information available on the virus to be detected (Naidu and Hughes, 2001). This review briefly traces the advanced and commonly used serological (viral coat protein-based) techniques for the detection and diagnosis of plant viruses.

\section{Plant Virus Diagnosis}

The terms diagnosis and detection are often used interchangeably. The diagnosis step involves a careful examination to determine the underlying cause of the disease; whereas detection is to find out the virus. Accurate detection and diagnosis of plant virus diseases is the initially vital step for the crop management system (AboulAta et al., 2011; Adams et al., 2013). Since after virus infection, chemical treatments/application to plants do not lead to effective control measures, plant viral diseases most effectively managed as control measures are applied before infection (Aboul-Ata et al., 2011). 
Monitoring plant health conditions and detecting pathogens early are essential to reduce the disease spread and facilitate successful management practices (Federico et al., 2014). Because of this, the development and the adaptation of efficient and rapid techniques for the detection and control of plant viruses constitute an imperative and relevant necessity (Albersio et al., 2012). Attempting to manage plant diseases caused by viruses without sufficient information and knowledge about their causal agents, their dissemination, and surviving properties, typically results in inadequate control. So, any attempt to establish a control strategy for a plant disease must be, always, preceded by a correct and precise field and laboratory diagnosis.

The identification, detection, and diagnosis of plant viruses rely on biological, serological and nucleic acidbased techniques, as well as the determination of the physical and chemical properties of the virus (Trigiano et al., 2008). In the fight against plant viral diseases, these techniques are very important for many diagnosticians for aiding the production of disease-free crops as well as for disease management strategies in the event of virus introduction and detection. The use of advanced methods for the identification and detection of viruses made the detection, easier and more sensitive (Mehetre et al., 2021). To date, numerous new methods for virus detection and diagnosis have been introduced; they are based on serological and nucleic acid analysis of plant viruses and include ELISA and PCR techniques and several of their variants.

\section{Traditional Detection Methods and their Limitation}

Traditional plant virus's detection and diagnosis were requiring bioassay, an indicator plant, determination of host range, symptomatology, virus particle morphology (size and shape), and vector relations (Fegla and El-Mazaty, 1981). The development of disease symptoms is the indication of plants being affected either by abiotic (environmental conditions) factors in fields or biotic (pests and pathogens) (Agrios, 2005).

Indeed, for virus detection and identification, symptoms can be the sole criterion upon which diagnosis is made, either in the primary host or following graft or sap transmission of the disease to a susceptible host. However, the only symptom-based identification has limitations because of factors including virus strain, host plant cultivar/variety, time of infection, and the environment can influence the symptoms exhibited (Matthews, 1980). Plants can also exhibit virus-like symptoms as a response to unfavorable weather conditions, soil mineral/nutrient imbalances, infection by non-viral pathogens, damage caused by insect/mite/nematode pests, air pollution, and pesticides (particularly herbicides). Some of the symptoms like stunting and chlorosis may not be virus infection but nutrient deficiencies (Nelson et al., 2011). Some plant viruses can induce no clear symptoms or cause symptomless infection.

In addition, different plant viruses can develop similar symptoms or different strains of a virus cause distinct symptoms in the same host (Jackie Hughes et al., 2004). In addition, symptoms possibly very slight and uncertain, infected plants may be symptomless (Lima et al., 2012) or different plant viruses can cause similar symptoms in a plant (Webster et al., 2004). Based on observation of plant virus symptoms has been less accurate, therefore, to be certain and to avoid misdiagnosis, other confirmatory identification tests must be conducted to make sure accurate diagnosis of virus infection (Varma and Singh, 2020). Generally, the biological methods including the search for good indicator host plants (those can potentially give prominent characteristic virus-infection symptoms), plantto-plant transmission, and host-range studies of the virus used for assay and detection of viruses are more timeconsuming in comparison with the other advanced and currently available diagnostic methods (Bhardwaj and Kulshrestha, 2020).

There are also traditional serological methods such as micro precipitin, tube precipitin, chloroplast agglutination, and gel diffusion involved direct observation of specific precipitates of virus and antibody, either in liquid media or agar gels. These methods require large quantities of reactants-antiserum and antigens for successful detection.

\section{Serological Techniques}

Detection and diagnosis of plant viruses have included serological tests since the 1960s (Martin et al., 2000) and have been extensively used for research, field diagnosis, seed and planting material certification programs, and plant quarantine (Varma and Singh, 2020). The serological detection and diagnosis of plant viruses are based on an antigen-antibody binding reaction between epitopes on the surface of virus particles and the binding sites of specific antivirus antibodies (van Regenmortel, 1982; Albersio et al., 2012; Bhardwaj and Kulshrestha, 2020).

The antigen is a molecule that when injected into a vertebrate animal (usually a mammal), can activate an immune response in the animal which results in the production of specific antibodies that can combine with the foreign antigen (Albersio et al., 2012; Bhardwaj and Kulshrestha, 2020). The antibody, also known as an immunoglobulin (Ig), is a Y-shaped protein molecule with a specific binding site against a particular antigen, secreted by B lymphocytes invertebrates. Each Y-unit contains four polypeptide chains-two identical copies of light $(\mathrm{L})$ chains and two identical copies of heavy $(\mathrm{H})$ chains joined to each other by disulfide bonds. Further, depending upon the number of Y-like units and the type of H-chain polypeptide that they contain, the antibodies are further classified into five types: $\operatorname{IgG}, \operatorname{IgM}$, IgE, IgA, and IgD (Bhardwaj and Kulshrestha, 2020). 
The immunoglobulin $\mathrm{G}(\mathrm{IgG})$ is the most common type of Ig produced and, consequently most commonly involved in the serological tests for plant virus identification. The IgG molecules are composed of three protein domains with two identical domains (Fab domains) containing the antigen-binding sites at the end of $\mathrm{Y}$ and one Fc domain is forming the stem of the Y. On the other hand, antigens are fairly large protein or non-protein molecules with specific regions (called "epitopes") to bind or interact with specific antibodies. The vertebral blood serum containing antibodies raised against a particular antigen is called "antiserum," and depending on the types of antibodies it contains, the antiserum can be of two types (i) polyclonal antibody (Pab), which contains antibodies against all the epitopes available on the antigen molecule, and (ii) monoclonal antibody (Mab) contains antibodies to only one epitope on the antigen (Ball et al., 1990; Jordan, 1990; Bhardwaj and Kulshrestha, 2020).

Generally, the methods that involve the antigen-antibody reactions in vitro are simple and do not require sophisticated and expensive materials (Albersio et al., 2012). The advanced and commonly used serological techniques, which include enzyme-linked immunosorbent assay, tissue blot immunosorbent assay and lateral flow devices are powerful tools for the detection of plant viruses based on an antigen-antibody binding reaction between epitopes on the surface of virus particles and the binding sites of specific antivirus antibodies.

\subsection{Enzyme-Linked Immunosorbent Assay (ELISA)}

ELISA is a very specific, simple, fast, and sensitive serological technique introduced to the study and identification of plant viruses in the 1970s (Clark \& Adams, 1977). ELISA has been used as a very popular assay to detect plant viruses within plant material, insect vectors, and seeds (Naidu and Hughes, 2001; Webster et al., 2004).

This method is able to detect viral particles at very low levels and due to its flexibility, high sensitivity, and economy in the use of reagents, ELISA is used in a variety of contexts, especially in diagnosing a large number of samples in a short period of time. The ELISA process is based on the basic mechanism by which viral antigens are detected by their specific antibodies ( $\mathrm{IgG}$ ) in combination with pigment structures. Ordinary ELISAs are made of polystyrene plate that bind to antibodies or proteins by the combination of the enzyme-substrate reaction and are usually achieved on 96-well polystyrene plate (microtitre plates) by adding antigens and antibodies to sources respectively, involving several phases. In the final stage, a positive reaction is obtained when a colorless substrate, usually pnitrophenyl phosphate, has a chemical reaction that results in a yellow color product as a result of exposure to the alkaline phosphate-binding enzyme. The color change rate indicates the degree of reactivity that is read by an ELISA plate reader device. It is always recommended to include a homologous antigen of a specific antibody of the virus and extracts from healthy plants to compare absorption reading and to obtain a proper interpretation of the results.

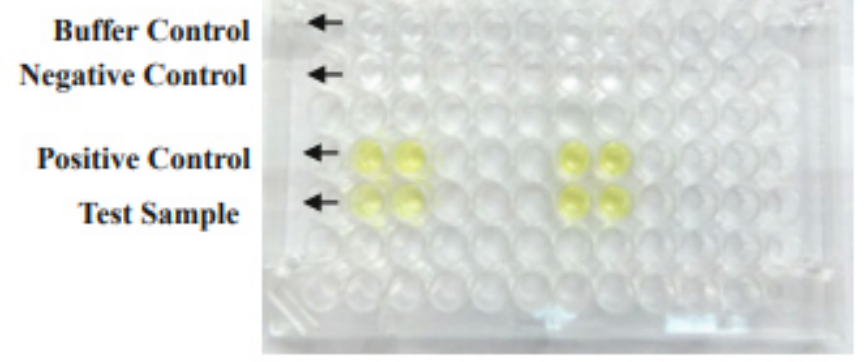

Fig. 1. A microtitre plate show results of ELISA test for virus detection after substrate addition. Yellow colour shows positive result. Buffer and negative controls (healthy leaf) did not show colour.

Although different variations of the ELISA technique have been developed, the double antibody sandwich, triple antibody sandwich, and direct antigen-coating are the most frequently used methods for diagnosis of plant virus diseases in a wide range of condition because of its sensitivity, adaptability, and economy in the use of reagent.

\subsubsection{Double antibody sandwich enzyme linked immunosorbent assay}

The double antibody sandwich (DAS-ELISA), is the most commonly used form of ELISA for plant virus disease diagnosis. The test method is referred to as DAS- ELISA because the virus is sandwiched between the capturing antibody and the detecting antibody (Almeida and Lima, 2001).

DAS-ELISA is performed in the following steps (Fig 2.): (1) the adsorption of virus-specific antibodies (the primary antibody $(\mathrm{IgG})$ produced against the virus to be detected) is added to the wells of the microtiter plates and allowed time to bind to the good walls. The unbound antibody is removed by washing. (2) The plant extracts (samples to be tested for virus antigen) are added for binding the IgGs coated previously (step 1). Controls include extracts from known infected plants (positive control), as well as extracts from healthy plants (negative control) added at this step. (3) After incubation and washing, the enzyme-antibody conjugate with the broadly used enzyme alkaline phosphatase or horseradish peroxidase is added and allowed to react with the virus being tested for. If a 
virus attached to the coating antibody is present, the enzyme-antibody conjugate will interact with the virus. Plates are washed. (4) A colorless substrate (p-nitrophenyl phosphate) is added, which develops color on reaction with the enzyme. Positive wells will show a yellow reaction, due to the action of the conjugated enzyme (alkaline phosphatase) on the substrate. Negative wells will remain colorless. The enzyme-substrate reaction is stopped by adding sodium hydroxide $(\mathrm{NaOH})$, and the intensity of the color can be scored visually on a predetermined scale or by using an ELISA reader using the filter for $405 \mathrm{~nm}$ wavelength (Mandal et al., 2012; Albersio et al., 2012; Suruthi et al., 2018; Varma and Singh, 2020; Bhat and Roa, 2020).

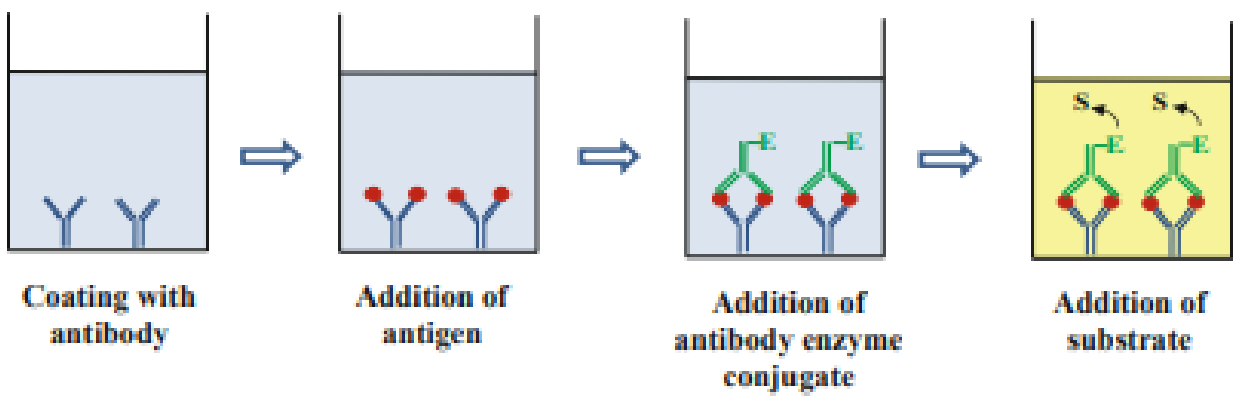

Fig. 2. Diagrammatic representation and basic steps in DAS-ELISA for detection of plant viruses. Source: Bhat and Roa, 2020.

\subsubsection{Direct antigen-coating}

Direct antigen-coating (DAC) is the simplest of ELISA forms as it detects the virus directly bound to the microtiter plates (Varma and Singh, 2020). DAC is to allow the virus, in the absence of any specific virus trapping layer as in DAS-ELISA, to adsorb on the plate surface by adding the test sample directly to the wells. In the second step, virus antibody (primary antibody) is added either as crude antiserum or IgG. The primary antibody is then detected with anti-species antibodies (secondary or detecting antibody) conjugated to an enzyme, followed by the addition of color development reagents. The detecting antibody binds specifically to the primary antibody since the former is produced against IgGs from the animal in which virus antibodies are raised (e.g., if virus antibodies are produced in rabbits, antirabbit IgGs are produced in a second species such as goats). It has certain disadvantages such as competition between plant sap and virus particles for sites on the plate and high background reactions (Naidu and Hughes, 2001; Albersio et al., 2012).

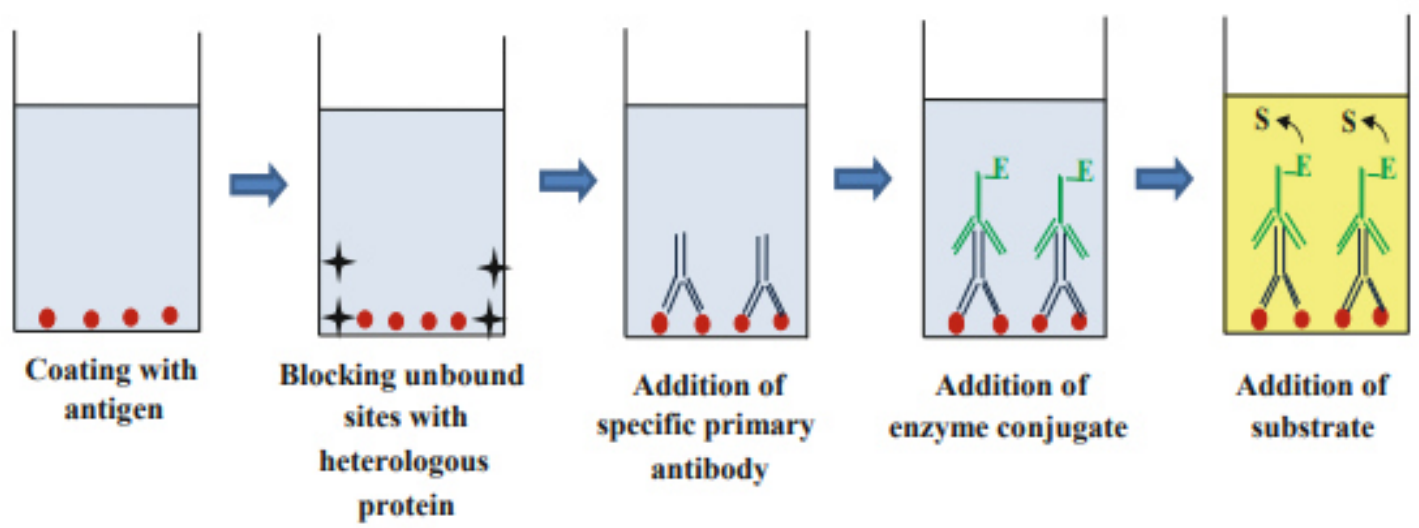

Fig. 3. Diagrammatic representation and basic steps of the direct antigen-coating method used for detection of plant viruses. Source: Bhat and Roa, 2020

\subsubsection{Triple antibody sandwich}

Another widely used ELISA form is the triple antibody sandwich (TAS- ELISA), which is similar to (DASELISA), except that an additional step is involved adding detecting antibody-enzyme conjugate. In this step, a monoclonal antibody, produced in another animal is used (Figure 3). The steps of TAS-ELISA: First, at the bottom of the ELISA plate wells are coated with a virus antibody produced in a species of animal (e.g., rabbit) and a viral antigen is attached to the captured. The viral antigen is covered by the second layer of virus-specific antibody produced in another animal species (e.g., mouse or goat) and the presence of the virus is detected by adding a specific anti-conjugated anti-mouse (e.g.), which does not react with the plate well-trapped antibody, followed by the color change of a particular substrate added into the wells. Considering that virus-specific monoclonal antibodies are generally used in the second layer of antibodies this procedure is an effective method of combining the broad reactivity of polyclonal antibodies in the virus trapping stage with the specificities of the monoclonal antibodies (Purcifull et al., 2001; Naidu and Hughes, 2001; Albersio et al., 2012; Bhat and Roa 2020). 


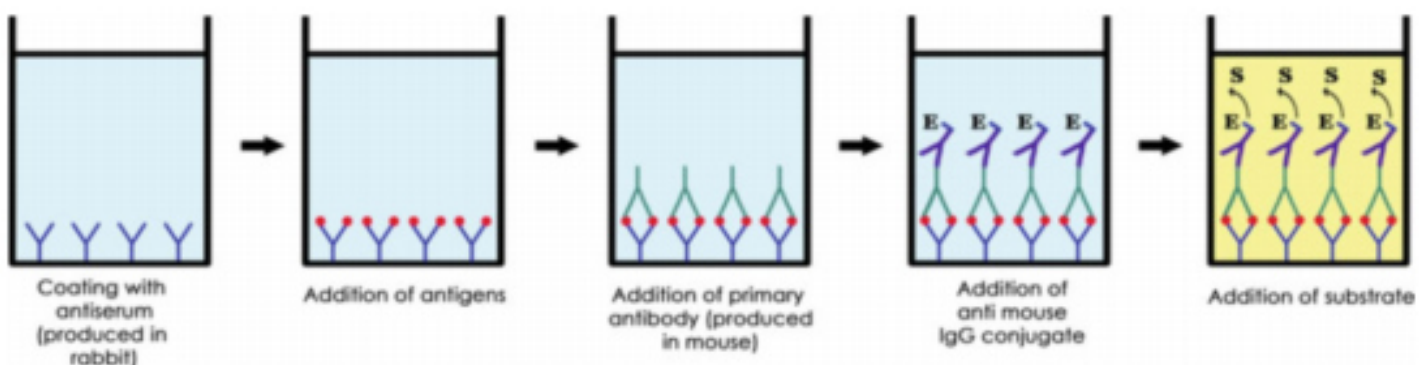

Fig. 4. Diagrammatic representation of the TAS-ELISA method used for detection of plant viruses. Source: Bhat and Roa, 2020

\subsection{Immunoblotting methods}

Serological solid support matrix devices similar to ELISA techniques were developed in which the virus antigens are trapped onto a membrane rather than in a microtitre plate. Like indirect ELISA, virus particles or their proteins are immobilized on nitrocellulose or nylon membranes (Almeida, 2001; Purcifull et al., 2001). As distinguished from indirect ELISA, it is not necessary to use an ELISA reader to detect viral interactions, and for this reason, it is not possible to quantify the results by numerical absorbance values (Almeida, 2001; Astier et al., 2007). Immunoblotting is also categorized into two main categories: Dot Immunoblotting Assay (DIBA) and Tissue Immunoblotting Assay (TIBA). The overall principle of DIBA and TBIA is similar to that of ELISA and both are suitable, sensitive, and cost-effective detection systems. These have been widely used for the diagnosis of viral diseases of plants (Hancevic et al., 2012; Shang et al., 2011).

\subsubsection{Dot immuno binding assay}

Dot blot immunoassay (DIBA), also called dot-ELISA, is simple as in this format nitrocellulose membrane (NCM) is used as a solid surface for binding antigen or antibody in the place of microtiter plates, and can be used in poorly equipped laboratories (Hawkes et al., 1982). DIBA is widely used for the detection in both plants and vectors (Matthews, 1980; Makkouk et al., 1993) for routine diagnosis of plant viruses.

The technique is similar to ELISA except that the plant extracts are spotted onto a membrane rather than using a microtitre plate as the solid support matrix (Almeida, 2001; Astier et al., 2007; Purcifull et al., 2001). The samples containing viral antigens are prepared by grinding tissues in Tris-buffered saline and extracts are applied directly to the membrane. The application of the sample to the membrane is usually accomplished by using a 96wells plastic mold that presses the membrane to mark the areas where the samples should be applied. Often, the spaces not occupied by the antigens on the membrane are blocked by neutral protein solution. The addition of virus IgG produced in the rabbit and the anti-rabbit IgG produced in mice follow protocols like indirect ELISA, except that the positive reactions in DIBA are recorded as colored dots on the membrane. Considering DIBA is a simple, less laborious and fast test, it can be used routinely for plant virus identification and survey programs (Almeida, 2001; Astier et al., 2007; Makkouk et al., 1993; Purcifull et al., 2001). One of the disadvantages of DIBA is that it is possible for the sap components to interfere with the antigen-antibody reactions, which has led to subsequent problems with the diagnostic results.

\subsubsection{Tissue blot immune assay}

The tissue blot immunoassay (TBIA) is similar to DIBA except that, as the name suggests, the virus is blotted directly from the infected tissue on to the NCM (Hancevic et al., 2012). TIBA is the simplest immunoblotting test designed to detect viral antigen in different types of plant and insect tissues. It is a variant of DIBA in which the samples consist of preparation of infected plant tissues. TIBA can be used to detect viral antigens in plant tissues such as leaf, stem, root, bulb, tuber, and fruit or insect vector of plant viruses. Tissues are cut with razor blades and pressed into the membrane to transfer viral particles or proteins (Makkouk et al., 1993; Purcifull et al., 2001). The present antigen was then detected by enzyme-labeled immunological probes (Fegla et al., 2001). For instance, Barley yellow dwarf viruses, Cereal yellow dwarf viruses, and Maize yellow dwarf virus (Bekele et al., 2018) were detected in tissue blots from infected leaves and stems. The presence of the virus in a blot of infected tissues developed purple color (Fig. 5). The healthy control leaf and stem blots did not develop purple color, but leaf blots reaction the green color of chlorophyll (Fegla et al., 2001). 


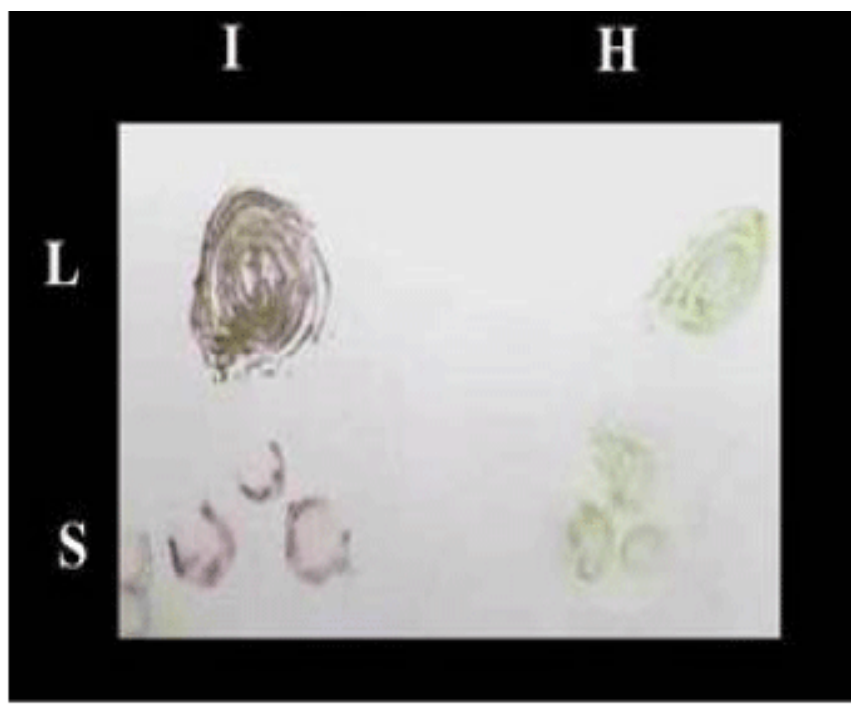

Fig 5. TBIA used for detection of Cucumber mosaic virus (CMV) in infected leaves and stemes of Nicotiana glutinosa plants on Nitrocellulose membrane. L: leaves, S: stems, I: infected, H: healthy. Source: Abd El-Aziz, 2019.

This method is also simple, does not require elaborate sample preparation or extraction, and provides information on the distribution of viruses in plant tissues (Lin et al., 1990; Hu et al., 1997). The detection of the virus antigens applied on the membrane is accomplished by protocols similar to those used for indirect ELISA and for DIBA. The TIBA method has been established to be sensitive enough to test the in-situ distribution of plant virus species from different families and genera (Astier et al., 2007; Makkouk et al., 1993). As in DIBA, the virusantibody interactions are not quantified because the results are not presented by numerical forms by absorbance values as in the ELISA variations (Almeida, 2001; Astier et al., 2007). The low cost and simplicity of these immunoblotting tests (DIBA and TIBA) make them useful in laboratories with limited facilities (Astier et. al., 2007; Makkouk and Kumari, 2002).

The major advantage of this test was the elimination of sap extraction, which is the most time-consuming step in all ELISA techniques. In addition, once the plant tissue is blotted on the nitrocellulose membrane, the test can be completed in a few days or a few months later. This is a great advantage in distant places, where facilities for processing nitrocellulose membrane membranes do not exist. In such locations, samples can be printed on nitrocellulose membrane membranes and then sent to distant locations for processing (Naidu and Hughes, 2001).

\subsection{Lateral flow immunoassay assay}

Lateral flow immunoassay (LFIA) is an immunochemical based method in which the fluid from a sample passes through a porous membrane (nitrocellulose) by capillary force. LFIAs are based on the principle of immunochromatography in which specific antigen and antibody interactions are responsible for color enhancement. LFAs are prefabricated strips of a carrier material containing dry reagents that work using a liquid sample. LFIAs are specially designed for use outside of the laboratory and are important for easy-to-use diagnostic purposes. The lateral-flow assay is a rapid (can give results in 5-15 minutes), simple (can be performed on the farm/field), and economical (does not require any special equipment) method (Drygin et al., 2011). The first lateral-flow assays described for plant viruses were for Cucumber mosaic cucumovirus and Tobacco mosaic tobamovirus (Tsuda et al., 1992). The lateral-flow assay, based on immunochromatography, is a rapid (can give results in 5-15 minutes), simple (can be performed on the farm), and economical (does not require any special equipment) method (Drygin et al., 2011).

Although there are a number of different immunoassay platforms, the Lateral flow devices formats are the most common ones that are commercially available. Lateral flow typically consists of a porous nitrocellulose membrane-bound to a narrow plastic strip on which pathogen-specific antibodies are immobilized in a band partway up the strip (De Boer and Lopez, 2012). Species-specific antibodies bound to micro particles of latex, colloidal gold, or silica is placed between the band of immobilized antibodies and a sample application pad. Immersion of the sample pad, located at one end of the strip, in a sample suspension allows sample liquid to wick up the strip by capillary forces. Antigens of the target pathogen bind to the particle-bound antibodies in the liquid flow and carry them to the band of immobilized antibodies trapping the specifically targeted antigens along with the bound reporter particles. Accumulation of bound particles makes the band visible to the naked eye and is indicative of a positive reaction (Posthuma-Trumple et al., 2009; De Boer and Lopez, 2012). The second capture line is the control line, containing species-specific antibodies designed to capture all unbound tagged antibodies 
that would also become visible to confirm that the assay has run correctly (Kulabhusan et al., 2017).

To perform the test, the infected tissue is ground in an extraction buffer and the tip of the strip is placed into the buffer. As the liquid moves up the wick, viral antigens are bound to gold flecks. As the infected sap continues to rise, the antigen is bound at an antibody line through antigen-antibody recognition binding. A positive result is displayed by the presence of two purple lines due to the accumulation of gold flecks at this antibody line and at the control line. Only one line, the control, is displayed for a negative result. Lateral-flow assay -based diagnostic kits have also been developed for specific detection of plant viruses and can be performed directly in the field (De Boer and Lopez, 2012; Varma and Singh, 2020).

As described by figure 5, a homogenized sample is given in the sample area $(\mathrm{S})$ where the virus responds with a specific antibody (IgG) mixed with colored dye. Both go with capillarity in the chromatographic membrane. The test line (T) contains specific antibodies to test for the pathogen. The control line (C) contains IgG-specific antibodies used. If the virus is present in the sample, once it has reached the test line, it responds with a specific polyclonal antibody and the colored conjugate that adheres to the virus produces a red line, indicating a positive result. The unbound antibodies continue to move to the control line and then the red line and show proper test performance. The trial requires minimal adjustment and achieves results within a few minutes.

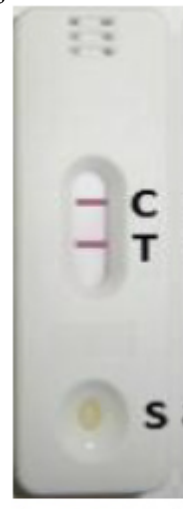

A

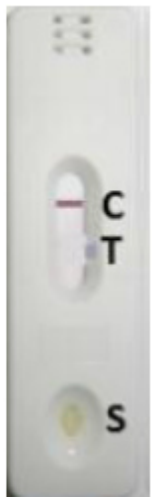

B

Fig 6. Lateral flow devices, the homogenized sample are dispensed on the sample spot (S). $\mathrm{A}=$ Positive samples show double red lines (test line $\mathrm{T}$ and control line $\mathrm{C}$ ), $\mathrm{B}=$ Negative sample (showing only control red line).

\subsection{Agristrip diagnostic}

AgriStrip, developed and produced by BIOREBA, AG, Reinach, Switzerland is based on lateral flow immunochromatography using specific antibodies. The principle of diagnosis plant viruses using Agristrip is similar with that of lateral flow assay except instead of dispensed on the sample spot (S), virus infected tissue is ground in an extraction buffer and the tip of the strip is placed into the buffer. Once the strip is dipped with the "sample" side into the sample extract, the liquid migrates upwards and initiates the antigen-antibody reaction which results in visible lines. As that of lateral flow, A positive result is displayed by the presence of two purple lines (both test and control lines become visible) (Fig 7A), whereas negative samples produce the upper control line only (Only one line, the control, is displayed for a negative result) (fig 7B). 


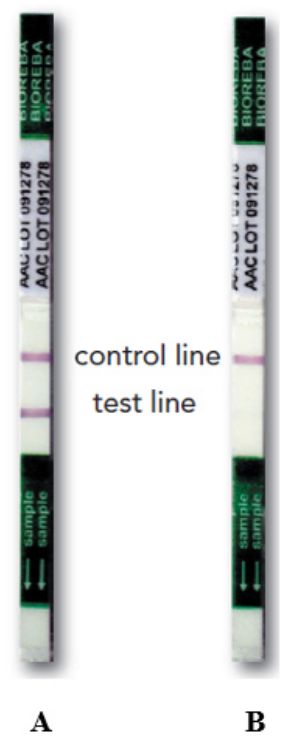

Fig. 7. AgriStrip test result (A, positive and B, negative)

Lines start developing after 1-2 minutes and reach maximum intensity after 10-15 minutes. Dried test strips can be kept as permanent records. The main advantage is time, as results are usually attained within 5-10 min.

\section{Conclusions}

Timely assessment and quickly detecting plant viral diseases are vital to reduce its spread and enable effective management practices. Proper detection and identification are always the primary step to developing effective and practical solutions to plant virus disease management. There are various current methods for detecting and identifying plant pathogens. Recent advances in biotechnology and molecular biology have played a major role in the development of rapid, precise and sensitive diagnostic tests. These new techniques are effective management tools that should be used in conjunction with plant knowledge, understanding of pathogen biology, and disease nature. The advanced serological detection technique is the commonly used based on the interaction of the coat protein properties of the virus and antibodies produced against them.

\section{References}

Abd El-Aziz, M. H. 2019. Three modern serological methods to detect plant viruses. J Plant Sci Phytopathology, 3: $101-106$

Aboul-Ata, A. E., Mazyad, H., El-Attar, A. K., Soliman, A. M., Anfoka, G., Zeidaen, M., Gorovits, R., Sobol, I. and Czosnek, H. 2011. Diagnosis and control of cereal viruses in the Middle East. Advances in Virus Research, 81: 33-61.

Adams, I. P., Miano, D. W, Kinyua, Z. M, Wangai, A., Kimani, E., Phiri, N., Reeder, R., Harju, V., Glover, R., Hany, U., Souza-Richards, R., Deb Nath, P., Nixon, T., Fox, A., Barnes, A., Smith, J., Skelton, A., Thwaites, R., Mumfordand, R. and Boonham, N. 2013. Use of next generation sequencing for the identification and characterization of Maize chlorotic mottlevirus and Sugarcane mosaic virus causing maize lethal necrosis in Kenya. Plant Pathology, 62: 741-749.

Agrios, G. N. 2005. Plant Pathology. 5th eddition. Elsevier Academic Press, 952.

Albersio, J., Lima, A., Nascimento, A. K., Radaelli, P. and Purcifull, D. E. 2012. Serology Applied to Plant Virology. In: Al-Moslih, M. (Ed.), Serological Diagnosis of Certain Human, Animal and Plant Diseases. InTech, DOI: $10.5772 / 38038$.

Almeida, A. and Lima, J. 2001. Técnicas sorológicas aplicadas à fitovirologia, In: Princípios e técnicas aplicados em fitovirologia, A.M.R. Almeida and J.A.A. Lima, (Eds.), 33-62, Edições Sociedade Brasileira Fitopatologia, ISBN 901648, Fortaleza, Ceará, Brazil

Almond, N., Jones, Heath, A. and Kitchin, P. 1992. The assessment of nucleotide sequence diversity by the polymerase chain reaction is highly reproducible. Journal of Virological Methods, 40: 37-44.

Astier, S., Albouy, J., Maury, Y., Robaglia, C., Lecoq, H. 2007. Principles of Plant Virology: Genome, pathogenicity, virus ecology, Science Publishers, ISBN: 1578083168, New Hampshire, USA.

Ball, E., Hampton, R. O., De Boer, S. H and Schaad, N.W. 1990. Polyclonal antibodies. Pages 33-54 in: Serological methods for the detection and identification of viral and bacterial plant pathogens: A laboratory manual, R. Hampton, E. Ball and S. De Boer, eds. APS Press, St. Paul, Minnesota.

Bekele, B., Kumari, S., Ahmed, S., Fininsa, C., Yusuf, A. and Abraham, A. 2018. Non-cultivated grass hosts of 
yellow dwarf viruses in Ethiopia and their epidemiological consequences on cultivated cereals. Journal of Phytopathology, 166:103-115.

Bhardwaj, A. and Kulshrestha, S. 2020. Advance methods for the isolation and characterization of plant viruses infecting crops. Applied Plant Virology, 39-53.

Bhat, A. I and Roa, P. G. 2020. Characterization of Plant Viruses: Methods and Protocols 1st eddition. Springer US; Humana press. ISBN: 978-1-0716-0333-8,978-1-0716-0334-5

Clark, M. F and Adamas, A. N. 1977. Characteristic of the microplate of enzyme-linked immunosorbent assay for the detection of plant viruses. Journal of General Virology, 34: 475-483.

De Boer, S. H., Mar' 1a, M. and Lopez, M. M. 2012. New Grower-Friendly Methods for Plant Pathogen Monitoring. Annual Review of Phytopathology, 50:197-218.

Drygin, Y. F., Blintsov, A. N., Grigorenko, V. G., Andreeva, I. P., Osipov, A. P., Varitzev, Y. A., Uskov, A. I., Kravchenko, D. V. and Atabekov, J. G. 2012. Highly sensitive field test lateral flow immunodiagnostics of PVX infection. Applied Microbiology and Biotechnology, 93: 179-189

Federico, M., Riccardo, S., Salvatore, D., Stefano, P., Giuseppe, S., Paolo, R., Paolo, V., Daniela, S., Mirco, B., Luiz, R. G., Cristina, E. D and Abhaya, M. D, 2014. Advanced methods of plant disease detection. Agronomy for Sustainable Development. DOI 10.1007/s13593-014-0246-1

Fegla, G. I and El-Mazaty, M. A. A. 1981. Distribution of certain viruses affecting cucurbits in Egypt and susceptibility of cucurbit cultivars to the most prevalent one. Alexandria Journal of Agricultural Research, 1: 247-258

Fegla, G. I., El-Samra, I. A., Younes, H. A. and Abd El-Aziz, M. H. 2001. Comparative studies for detection of Tomato Mosaic Tobamovirus (ToMV), Cucumber Mosaic Cucumovirus (CMV) and Potato Y Potyviruses (PVY). Advances in Virus Research, 6: 239-254.

Han cinský, R., Mihálik, D., Mrkvová, M., Candresse, T. and Glasa, M. 2020. Plant viruses infecting Solanaceae family members in the cultivated and wild environments: A review. Plants, 9, 667.

Hancevic, K., Cerni, S., Radic, T. and Skoric, D. 2012. Comparison of different methods for Citrus tristeza virus detection in Satsuma mandarins. Journal of Plant Diseases and Protection, 119 (1), 2-7.

Hawkes, R., Niday, E. and Gordon, J. 1982. A dot-immunobinding assay for monoclonal and other antibodies. Analytical Biochemistry, 119 (1), 142-147.

Hu, J. S, Sether, D. M., Liu, X. P. and Wang, M. 1997. Use of tissue blotting immunoassay to examine the distribution of pineapple closterovirus in Hawaii. Plant Disease, 81: 1150-1154.

Janse, J., van den Beld, H. E., Elphinstone, J., Simpkins, S., Tjou-Tam-Sin, N. N. A. and Van Vaerenbergh, J. 2004. Introduction to Europe of Ralstonia solanacearum biovar 2, race 3 in Pelargonium zonale cuttings. Journal of Plant Pathology, 86, 147-155.

Jordan, R. L. 1990. Strategies and techniques for the production of monoclonal antibodies; monoclonal antibody applications for viruses. Pages 55-86 in: Serological methods for the detection and identification of viral and bacterial plant pathogens: A laboratory manual, R. Hampton, E. Ball and S. De Boer, eds. APS Press, St. Paul, Minnesota.

Kulabhusan, P. K., Rajwade, J. M., Sugumar, V. T. G., Hameed, A. S. and Paknikar, K. M. 2017. Field-usable lateral flow immunoassay for the rapid detection of white spot syndrome virus (WSSV). PLoS One 3:2017. https://doi.org/10.1371/jour nal.pone.0169012

Lima, J. A. A., Nascimento, A. K. Q., Radaelli, P. and Purcifull, D. E. 2012. Serology applied to plant virology. Serological diagnosis of certain human, animal and plant diseases. Rijeka Croácia. In Tech pp. 71-94.

Lin, N. S., Hsu, Y. H. and Hsu, H. T. 1990. Immunological detection of plant viruses and mycoplasmalike organisms by direct tissue blotting on nitrocellulose membranes. Phytopathology, 80: 824-828.

Makkouk, K. M., Hsu, H. and Kumari, T. 1993. Detection of three plant viruses by dot-blot and tissue-blot immunoassays using chemiluminescent and chromogenic substrates. Journal of Phytopathology, 139: 97102.

Makkouk, K.M. and Kumari, S.G. 2002. Low-cost paper can be used in tissue-blot immunoassay for detection of cereal and legume viruses. Phytopathologia Mediterranea, 41 (3), 275-278.

Maksimov, I.V., Sorokan, A.V., Burkhanova, G. F., Veselova, S.V., Alekseev, V.Y., Shein, M.Y., Avalbaev, A. M., Dhaware, P. D., Mehetre, G.T., Singh, B. P. 2019. Mechanisms of plant tolerance to RNA viruses induced by plant-growth-promoting microorganisms. Plants, 8, 575.

Mandal, B., Vijayanandraj, S., Shilpi, S., Pun, K. B., Singh, V., Pant, R. P., Jain, R. K., aradarasan, S. V. and Varma A. 2012. Disease distribution and characterisation of a new macluravirus associated with chirke disease of large cardamom. Annals of Applied Biology, 160 (3), 225-236.

Matthews, R. E. 1980. Host plant responses to virus infection. Pages 297-359 in Comprehensive virology, vol. 16, virus-host interaction, viral invasion, persistence, and diagnosis, edited by H. Fraenkel-Conrat and R.R. Wagner. Plenum Press, New York, USA.

Mehetre, G.T., Leo, V.V., Singh, G., Sorokan, A., Maksimov, I., Yadav, M. K., Upadhyaya, K., Hashem, A., 
Alsaleh, A. N., Dawoud, T.M., Almaary, K. S. and Singh, B. P. 2021. Current Developments and Challenges in Plant Viral Diagnostics: A Systematic Review. Viruses, 13, 412.

Naidu, R. A and Hughes, J. A. 2001. Methods for the detection of plant virus diseases, In: Plant virology in subSaharan Africa, J.d'A. Hughes \& B. O. Odu, (Eds.), 233-260, Proceedings of a Conference Organized by IITA, International Institute of Tropical Agriculture, ISBN 9781312149, Nigeria.

Nelson, S., Brewbaker, J. and Hu, J. 2011. Maize chlorotic mottle. PD-79. College of Tropical Agriculture and Human Resources, University of Hawaii at Manoa.

Posthuma-Trumple, G. A., Korf, J. Van Amerongen, A. 2009. Lateral flow (inmuno) assay: its strengths, weakness, opportunities and threats. A literature surveys. Analytical and Bioanalytical Chemistry, 393:569-82

Purcifull, D. E., Hiebert, E., Petersen, M. and Webb, S. 2001. Virus detection - Serology, In: Encyclopedia of Plant Pathology, O. C. Maloy and T. D. Murray, (Eds.), Vol. 2, 1100-1109, John Wiley \& Sons, Inc. ISBN: 0-471-29817-4

Savary, S., Ficke, A., Aubertot, J and Hollier, C. 2012. Crop losses due to diseases and their implications for global food production losses and food security. Food Security, 4:519-537.

Shang, H., Xie, Y., Zhou, X., Qian, Y. and Wu, J. 2011. Monoclonal antibody-based serological methods for detection of Cucumber green mottle mosaic virus. Virology Journal, 8 (1), 228.

Suruthi, V., Nakkeeran, S., Renukadevi, P., Malathi, V. G and Rajasree, V. 2018. Evidence of seed transmission of dolichos yellow mosaic virus, a begomovirus infecting lablab-bean in India. Virus Dis. Available from: https://doi.org/10.1007/s13337-018-0494-9.

Trigiano, R. N., Windham, M. T and Windhan, A. S. (Eds.), (2008). Plant pathology, concepts and laboratory exercises. CRC Press 21:269.

Tsuda, S., Kameya-Iwaki, M., Hanada, K., Kouda, Y., Hikdtd, M. and Tomaru, K. 1992. A novel detection and identification technique for plant viruses: rapid immunofilter paper assay (RIPA). Plant Disease, 76,466-469.

Van Regenmortel, M. H. V. 1982. Serology and immunochemistry of plant viruses. Academic Press, New York, USA.

Varma, A. and Singh, M. K. 2020. Diagnosis of plant virus diseases. Applied Plant Virology, 79-92.

Webster, C. G., Wylie, S. J. and Jones, M. G. 2004. Diagnosis of plant viral pathogens. Current Science, 86(12):1604-1607. 